\title{
Salicylic Acid Improves Root Antioxidant Defense System and Total Antioxidant Capacities of Flax Subjected to Cadmium
}

\author{
Aïcha Belkadhi, ${ }^{1,2}$ Antonio De Haro, ${ }^{2}$ Pilar Soengas, ${ }^{3}$ Sara Obregon, ${ }^{2}$ Maria Elena Cartea, ${ }^{3}$ \\ Wahbi Djebali, and Wided Chaïbi ${ }^{1}$
}

\begin{abstract}
Cadmium (Cd) disrupts the normal growth and development of plants, depending on their tolerance to this toxic element. The present study was focused on the impacts of exogenous salicylic acid (SA) on the response and regulation of the antioxidant defense system and membrane lipids to 16-day-old flax plantlets under Cd stress. Exposure of flax to high $\mathrm{Cd}$ concentrations led to strong inhibition of root growth and enhanced lipid peroxides, membrane permeability, protein oxidation, and hydrogen peroxide $\left(\mathrm{H}_{2} \mathrm{O}_{2}\right)$ production to varying degrees. Concomitantly, activities of the antioxidant enzymes catalase (CAT, EC 1.11.1.6), guaiicol peroxydase (GPX, EC 1.11.1.7), ascorbate peroxydase (APX, EC 1.11.1.11), and superoxide dismutase (SOD, EC 1.15.1.1), and the total antioxidant capacities (2,2'-diphenyl-1-picrylhydrazyl (DPPH) scavenging activity and ferric reducing antioxidant power (FRAP)) were significantly altered by $\mathrm{Cd}$. In contrast, exogenous SA greatly reduced the toxic effects of $\mathrm{Cd}$ on the root growth, antioxidant system, and membrane lipid content. The Cd-treated plantlets presoaked with SA exhibited less lipid and protein oxidation and membrane alteration, as well as a high level of total antioxidant capacities and increased activities of antioxidant enzymes except of CAT. These results may suggest that SA plays an important role in triggering the root antioxidant system, thereby preventing membrane damage as well as the denaturation of its components.
\end{abstract}

\section{Introduction}

$\mathbf{R}$ OOTS ARE THE FIRST PART of the plant to respond to metal stress. Cadmium (Cd) stress may disturb plant nutrient balance (Belkhadi et al., 2010, Douchiche et al., 2010), inhibit growth (Hédiji et al., 2010, Gallego et al., 2012), and generate oxidative stress (Tamás et al., 2007). It is well known that $\mathrm{Cd}$ is a non-redox-active metal that does not trigger the direct formation of hydroxyl radicals $(\mathrm{OH})$ via Haber-Weiss and Fenton reactions, but indirectly, by disturbing the chloroplast and mitochondria electron transport rates (Hendry et al., 1992) and/or by inducing loss in enzymatic and nonenzymatic antioxidative system capacities (Gratão et al., 2005, Rodriguez-Serrano et al., 2009, Gallego et al., 2012).

The oxidative stress induced by $\mathrm{Cd}$ can also be correlated with damage to membrane lipids (Djebali et al., 2005; Belkhadi et al., 2010), nucleic acids (Apel and Hirt, 2004, Gichner et al., 2004) and proteins (Djebali et al., 2008, Douchiche et al.,
2010). In response to reactive oxygen species (ROS), plants can induce a succession of detoxification reactions catalyzed by antioxidative enzymes (Gratão et al., 2012). However, in comparison of some species, $\mathrm{Cd}$ treatment can be seen to have opposite effects on certain antioxidative enzymes. In Bacopa monnieri L., Cd induced elevated superoxide dismutase (SOD, EC 1.15.1.1), guaïcol peroxydase (GPX, EC 1.11.1.7), ascorbate peroxidase (APX, EC 1.11.1.11), and glutathione reductase (GR, EC 1.6.4.2), but decreased catalase (CAT, EC 1.11.1.6) activities (Mishra et al., 2006). Severe diminution of peroxidase (POX, EC 1.11.1.7) and CAT activities were found in Oryza sativa roots, while in contrast to B. monnieri, SOD activity was also diminished (Guo et al., 2007). An increase in CAT activity under $\mathrm{Cd}$ stress has been found in other species (Balestrasse et al., 2001, Smeets et al., 2008).

Salicylic acid (SA) is a biomolecule that may be involved in several cell processes under normal and stress conditions. Under biotic and abiotic stress conditions, increasing evidence

\footnotetext{
${ }^{1}$ Département de Biologie, Unité de Recherche de Physiologie et Biochimie de la tolérance des plantes aux contraintes abiotiques, Faculté des Sciences de Tunis, Campus Universitaire, Tunis, Tunisia.

${ }^{2}$ Department of Agronomy and Plant Breeding, Institute of Sustainable Agriculture, Spanish Council for Scientific Research (CSIC), Córdoba, Spain.

${ }^{3}$ Department of Plant Genetics, Misión Biológica de Galicia, Spanish Council for Scientific Research (CSIC), Pontevedra, Spain.
} 
indicates that SA, a phytohormone that acts at low concentrations, is produced and accumulates inside cells to function as a signaling molecule in plants (Choi et al., 2012, Hao et al., 2012). SA is involved in gene expression in response to multiple stresses (Durrant and Dong, 2004, Fobert and Despres, 2005, Foyer and Noctor, 2005). When applied exogenously at appropriate concentrations, SA enhanced the efficiency of antioxidant system in plants (Radwan 2012, Saruhan et al., 2012). Furthermore, SA application has been reported to alleviate the symptoms of Cd toxicity observed in plants (Zawoznik et al., 2007; Zhang and Chen, 2011). Previous studies have shown that SA treatment mitigates the oxidative stress generated by $\mathrm{Cd}$ in different plant species such as barley (Metwally et al., 2003), soybean (Drazic and Mihailovic, 2005), rice (Guo et al., 2007), maize (Krantev et al., 2008), pea (Popova et al., 2009), and hemp (Shi et al., 2009). However, little has been reported about the role of SA in the increase of total antioxidant capacities under Cd stress. In the present study, we aim to characterize the mechanism by which SA protects plants against lipid and protein oxidative damage caused by Cd exposure. In roots, Zhang et al. (2011) have demonstrated that SA-induced Cd tolerances in Phaseolus aureus and Vicia sativa were related to increases in symplastic and apoplastic antioxidant enzyme activities. Recent study also reported that the priming of seeds with lower concentrations of SA, before sowing, lowered the elevated levels of ROS due to Cd exposure and enhanced the activities of various antioxidant enzymes (CAT, GPX, GR, and SOD) in Oryza sativa, thereby protecting the plants from oxidative burst (Panda and Patra, 2007). However, contrary to this observation, Choudhury and Panda (2004) reported a decline in the activities of the antioxidant enzymes CAT, POX, SOD, and GR in rice following the pre-treatment with SA.

Taken together, this work provides novel avenues toward understanding the mechanisms of plant enhancement of tolerance to Cd-mediated oxidative stress by using SA priming event and its possible function in the restoration and maintenance of the cell membrane integrity in roots. To test this possibility, SA-related changes in hydrogen peroxide $\left(\mathrm{H}_{2} \mathrm{O}_{2}\right)$ production, membrane integrity, antioxidant capacities, and membrane lipid content and fatty acid profiles have been studied in roots of Cd-treated flax plantlets.

\section{Materials and Methods}

Flax seeds (cv. Viking) were soaked for $8 \mathrm{~h}$ in SA solutions as previously shown in Belkhadi et al. (2010). They were then germinated for 4 days at $25^{\circ} \mathrm{C}$ in the dark. Uniform plantlets were transferred to a continuously aerated nutrient solution (pH 5.5) containing $1 \mathrm{mM} \mathrm{MgSO}, 2.5 \mathrm{mM} \mathrm{Ca}\left(\mathrm{NO}_{3}\right)_{2}, 1 \mathrm{mM}$ $\mathrm{KH}_{2} \mathrm{PO}_{4}, 2 \mathrm{mM} \mathrm{KNO}{ }_{3}, 2 \mathrm{mM} \mathrm{NH}{ }_{4} \mathrm{Cl}, 50 \mathrm{mM}$ EDTA- Fe-K, $30 \mathrm{mM} \mathrm{H}_{3} \mathrm{BO}_{3}, 10 \mathrm{mM} \mathrm{MnSO}, 1 \mathrm{mM} \mathrm{ZnSO}, 1 \mathrm{mM} \mathrm{CuSO}_{4}$ and $30 \mathrm{mM}(\mathrm{NH} 4)_{6} \mathrm{Mo}_{7} \mathrm{O}_{24}$. The nutrient solution was buffered with $\mathrm{HCl} / \mathrm{KOH}$ and changed twice per week. After growing for 2 days, plantlets were subjected during 10 days to $\mathrm{CdCl}_{2}$ appropriately from moderate to high concentrations (50 to $100 \mu \mathrm{M})$. Five replicates were in individual 61 plastic beakers made for control and $\mathrm{Cd}$ treatments. Plantlets were grown in a growth chamber at a day/night cycle of $16 \mathrm{~h} / 8 \mathrm{~h}$, at $23^{\circ} \mathrm{C} / 18^{\circ} \mathrm{C}$, respectively, a relative humidity close to $75 \%$ and a light intensity of $200 \mu \mathrm{mol}$ photons $\mathrm{m}^{-2} \mathrm{~s}^{-1}$. Roots were then detached, washed with deionized water and immedi- ately used or frozen at $-80^{\circ} \mathrm{C}$. Three independent culture experiments were performed.

Roots of the harvested plantlets were washed carefully using distilled water to eliminate any contamination. Root diameter, surface area, and volume were recorded by THSCSA Image Tool (IT) Version 3.0. Three plantlets from each replication of all treatments were selected for data collection.

The level of lipid peroxidation in roots was determined as 2-thiobarbituric acid (TBA) reactive metabolites, chiefly malondialdehyde (MDA), as described previously by Buege and Aust (1972). Membrane permeability of roots was determined as follows. Root tissue $(0.1 \mathrm{~g})$ was vibrated for $30 \mathrm{~min}$ in deionized water, followed by measurement of conductivity of bathing medium (EC1). Then, the samples were boiled for $15 \mathrm{~min}$ and the final conductivity (EC2) of the medium was measured using a conductivity meter (Consort C832).

Root samples were homogenized in $0.2 \mathrm{~N}$ perchloric acid ( $\mathrm{pH}$ 7.5). The flax $\mathrm{H}_{2} \mathrm{O}_{2}$ content in roots was determined as described by O'Kane et al. (1996). Protein-bound carbonyl content was determined by using the dinitrophenylhydrazine (DNPH) method, according to Reznick and Packer (1994). The level of carbonyl groups was estimated using an extinction coefficient of $22,000 \mathrm{M}^{-1} \mathrm{~cm}^{-1}$.

Total SOD activity was assayed by monitoring the inhibition of the photochemical reduction of nitroblue tetrazolium (NBT) according to the method of Beauchamp and Fridovich (1971). One unit of SOD activity was defined as the amount of enzyme required to cause $50 \%$ inhibition in the reduction of NBT as monitored at $560 \mathrm{~nm}$. For the assay of APX activity, $2 \mathrm{mM}$ ascorbate was added in the extraction medium. The reaction mixture containing $50 \mathrm{mM}$ potassium phosphate $(\mathrm{pH}$ 7.0), $0.1 \% \mathrm{H}_{2} \mathrm{O}_{2}, 0.5 \mathrm{mM}$ ascorbate (extinction coefficient $2.8 \mathrm{mM}^{-1} \mathrm{~cm}^{-1}$ ) and root extract induced a linear decrease in absorbance at $290 \mathrm{~nm}$ for $25 \mathrm{~s}$ (Nakano and Asada, 1981). GPX activity was measured according to Landberg and Greger (2002) following the change in absorption at $470 \mathrm{~nm}$. CAT activity was determined by following the consumption of $\mathrm{H}_{2} \mathrm{O}_{2}$ (extinction coefficient $39.4 \mathrm{mM}^{-1} \mathrm{~cm}^{-1}$ ) at $240 \mathrm{~nm}$ for $30 \mathrm{~s}$ (Aeby, 1984). Soluble protein contents in enzyme extracts were determined by the method of Bradford (1976).

For antioxidant potential analysis, extracts were prepared following Ferreres et al. (2007). $20 \mathrm{mg}$ of powder material was suspended in $2 \mathrm{~mL}$ of Milli-Q water, then boiled for $1 \mathrm{~h}$ at $100^{\circ} \mathrm{C}$. Suspension was filtered and supernatant lyophilized (BETA 2-8 LD plus, Christ). The dry material was weighed and dissolved in Milli-Q water to reach a concentration of $10 \mathrm{mg} \mathrm{mL}^{-1}$. Antioxidant potential of the samples was determined spectrophotometrically by monitoring the disappearance of radical DPPH according to the method of Brand-Williams et al. (1995). Readings were taken at $517 \mathrm{~nm}$ after $1 \mathrm{~h}$ of incubation at room temperature in a microplate reader (Spectra MR, DYNEX Technologies). After subtracting the value of the blank from each sample, absorbance was plotted against concentration of samples, EC50 values (concentrations which produced 50\% inhibition) were computed for each extract and were used to compare among samples. Antioxidant potential of the samples was also measured by the FRAP assay developed by Benzie et al. (1996). Readings were taken at $593 \mathrm{~nm}$ after $1 \mathrm{~h}$ at room temperature. Sample absorbance was plotted against concentration of samples; the concentration which produced an absorbance of 1.00 was 
Table 1. Effect of SA on Root Growth of 16-Day-Old Cd-Treated Flax Plantlets

\begin{tabular}{lcccccc}
\hline \multirow{2}{*}{$\begin{array}{l}S A \\
(\mu \mathrm{M})\end{array}$} & $\begin{array}{c}C d \\
(\mu \mathrm{M})\end{array}$ & $\begin{array}{c}\text { Dry weight } \\
\left(\mathrm{mg} \mathrm{plant}^{-1}\right)\end{array}$ & $\begin{array}{c}\text { Length } \\
(\mathrm{cm})\end{array}$ & $\begin{array}{c}\text { Diameter } \\
(\mathrm{mm})\end{array}$ & $\begin{array}{c}\text { Surface } \\
\left(\mathrm{dm}^{2} \text { plant }^{-1}\right)\end{array}$ & $\begin{array}{c}\text { Volume } \\
\left(\mathrm{cm}^{3} \mathrm{plant}^{-1}\right)\end{array}$ \\
\hline 0 & 0 & $5.51 \pm 0.27^{\mathrm{e}}$ & $31.78 \pm 1.81^{\mathrm{bc}}$ & $2.44 \pm 0.15^{\mathrm{c}}$ & $14.16 \pm 1.19^{\mathrm{d}}$ & $19.34 \pm 1.17^{\mathrm{d}}$ \\
0 & 50 & $4.34 \pm 0.15^{\mathrm{bc}}$ & $16.09 \pm 0.8^{\mathrm{e}}$ & $1.33 \pm 0.03^{\mathrm{ab}}$ & $3.83 \pm 0.21^{\mathrm{b}}$ & $2.70 \pm 0.3^{\mathrm{b}}$ \\
0 & 100 & $3.21 \pm 0.13^{\mathrm{a}}$ & $12.05 \pm 1.13^{\mathrm{e}}$ & $1.04 \pm 0.02^{\mathrm{a}}$ & $1.63 \pm 0.06^{\mathrm{a}}$ & $1.19 \pm 0.05^{\mathrm{a}}$ \\
250 & 0 & $5.21 \pm 0.1^{\mathrm{cd}}$ & $45.69 \pm 2.3^{\mathrm{cd}}$ & $3.16 \pm 0.2^{\mathrm{cd}}$ & $13.39 \pm 0.7^{\mathrm{d}}$ & $51.78 \pm 2.3^{\mathrm{g}}$ \\
250 & 50 & $5.55 \pm 0.2^{\mathrm{ef}}$ & $31.82 \pm 1.5^{\mathrm{bc}}$ & $2.69 \pm 0.11^{\mathrm{b}}$ & $7.08 \pm 0.26^{\mathrm{c}}$ & $21.38 \pm 1.5^{\mathrm{e}}$ \\
250 & 100 & $4.26 \pm 0.11^{\mathrm{ab}}$ & $18.23 \pm 0.13^{\mathrm{a}}$ & $1.16 \pm 0.1^{\mathrm{a}}$ & $2.94 \pm 0.02^{\mathrm{ab}}$ & $3.03 \pm 0.3^{\mathrm{bc}}$ \\
1000 & 0 & $5.59 \pm 0.21^{\mathrm{ef}}$ & $40.90 \pm 1.7^{\mathrm{d}}$ & $3.57 \pm 0.25^{\mathrm{d}}$ & $16.01 \pm 1.22^{\mathrm{e}}$ & $46.88 \pm 2.1^{\mathrm{f}}$ \\
1000 & 50 & $4.75 \pm 0.25^{\mathrm{cd}}$ & $25.80 \pm 2.31^{\mathrm{b}}$ & $1.41 \pm 0.03^{\mathrm{ab}}$ & $4.13 \pm 0.13^{\mathrm{bc}}$ & $7.37 \pm 0.24^{\mathrm{c}}$ \\
1000 & 100 & $3.75 \pm 0.07^{\mathrm{a}}$ & $14.20 \pm 0.7^{\mathrm{e}}$ & $1.28 \pm 0.13^{\mathrm{ab}}$ & $1.81 \pm 0.02^{\mathrm{a}}$ & $2.03 \pm 0.19^{\mathrm{ab}}$ \\
\hline
\end{tabular}

${ }^{\mathrm{a}}$ Data are means of three independent experiments $( \pm \mathrm{SE}) .{ }^{\mathrm{b}}$ Means with different letters indicate statistically different results at $p \leq 0.05$, according to Tukey's (HSD) test.

computed and was used to compare among samples. For both assays, three replications were analyzed for each sample and standard prepared with different concentrations of Trolox ${ }^{\circledR}$ were also measured. The results were expressed in $\mu \mathrm{mol}$ Trolox $\mathrm{g}^{-1}$ dry weight (DW).

Lipids in roots were extracted according to Garcés and Mancha (1993) using $30 \mathrm{mg}$ plant tissue. Fatty acids were identified by comparing the retention times of flax root methyl esters with those of known mixtures of standard fatty acids (Sigma) run on the same column under the same conditions.

Statistical calculations were performed with SPSS-17 statistical software. Mean difference comparison among different treatments was done by ANOVA and Tukey's (HSD) test at a 0.05 probability level.

\section{Results}

When Cd was present in the nutrient solution, flax plantlets exhibited reduced root growth. Root dry weight, length, diameter, surface, and volume decreased proportionally with increasing concentrations of $\mathrm{Cd}$ (Table 1). In contrast, presoaking with SA for $8 \mathrm{~h}$ led to an increase in the root growth parameters in a Cd-dependent manner. As a result, already after 10 days exposure to $\mathrm{Cd}$, the whole root system appeared less short and thick (Fig. 1).

In roots, $\mathrm{Cd}$ treatments showed a significant increase of $\mathrm{H}_{2} \mathrm{O}_{2}$ content compared with control (Fig. 2A). It increased by about $37 \%$ over control at $50 \mu \mathrm{MCd}$ and was further enhanced to nearly $62 \%$ more over control at $100 \mu \mathrm{M} \mathrm{Cd}$. However, upon the 8-h SA pretreatment, there was no significant decrease in the $\mathrm{H}_{2} \mathrm{O}_{2}$ content in flax roots compared to those with $\mathrm{Cd}$ only (Fig. 2A).

The damage by $\mathrm{Cd}$ to membranes was investigated by monitoring MDA content and electrolyte leakage (Fig. 2B and C). Relative to the control, Cd-treated flax plantlets exhibited a higher rate of lipid peroxidation. However, it was observed that 8-h SA pretreatment exhibited a significant reduction of Cd-increased MDA content (Fig. 2B). Electrolyte leakage was also altered by the 8-h SA pretreatment, but the extent of change was not as great as the change in the MDA level (Fig. $2 \mathrm{C})$. Only at $100 \mu \mathrm{M} \mathrm{Cd}$, the electrolyte leakage level in roots increased significantly by 1.6-fold as compared with the control. 8-h SA pretreatment counteracted the Cd-induced loss of membrane permeability. At the highest metal concentration, the most prominent effect was at $1000 \mu \mathrm{M} \mathrm{SA}$; a nearly $46 \%$ decrease was noticed (Fig. 2C). Significant increases in total protein content were observed between treated and control flax plantlets irrespective of the $\mathrm{Cd}$ concentration, (Fig. 2D). Within both Cd concentrations (50 and $100 \mu \mathrm{M}), 8$-h SA pretreatment led to restoration of the protein content and that in a dose dependent way. Thus, at $100 \mu \mathrm{M}$ Cd-treated plantlets, SA (250 or $1000 \mu \mathrm{M})$ inhibited the amount of protein oxidation in roots by about 2.4- and 1.4fold, respectively, compared to control (Fig. 2E).

The effect of $\mathrm{Cd}$ on the activities of antioxidative enzymes (Fig. 3A-D) was significant in most Cd-exposed roots. CAT activity was significantly increased in Cd-treated roots while,

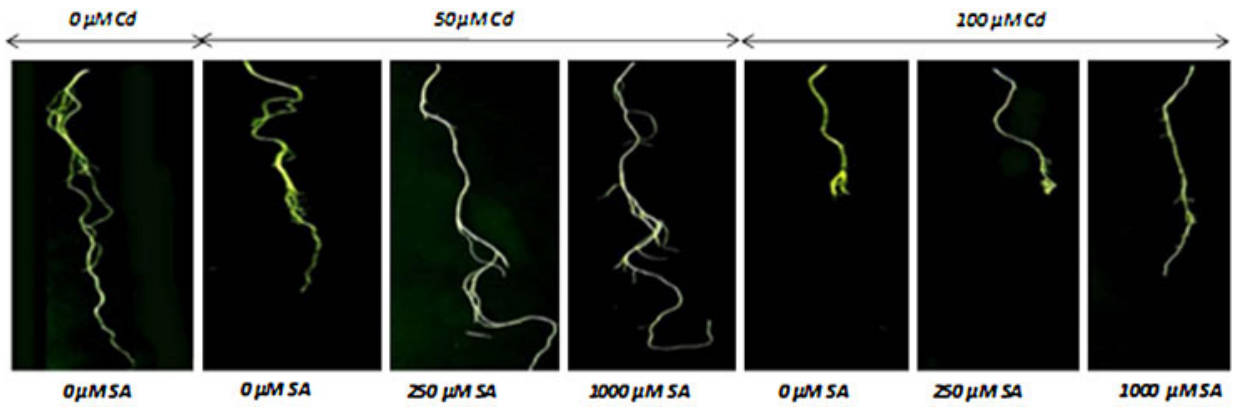

FIG. 1. Root morphological aspects of SA-pretreated flax plantlets grown in hydroponics culture and subjected for 10 days to increased $\mathrm{CdCl}_{2}$ concentrations. 

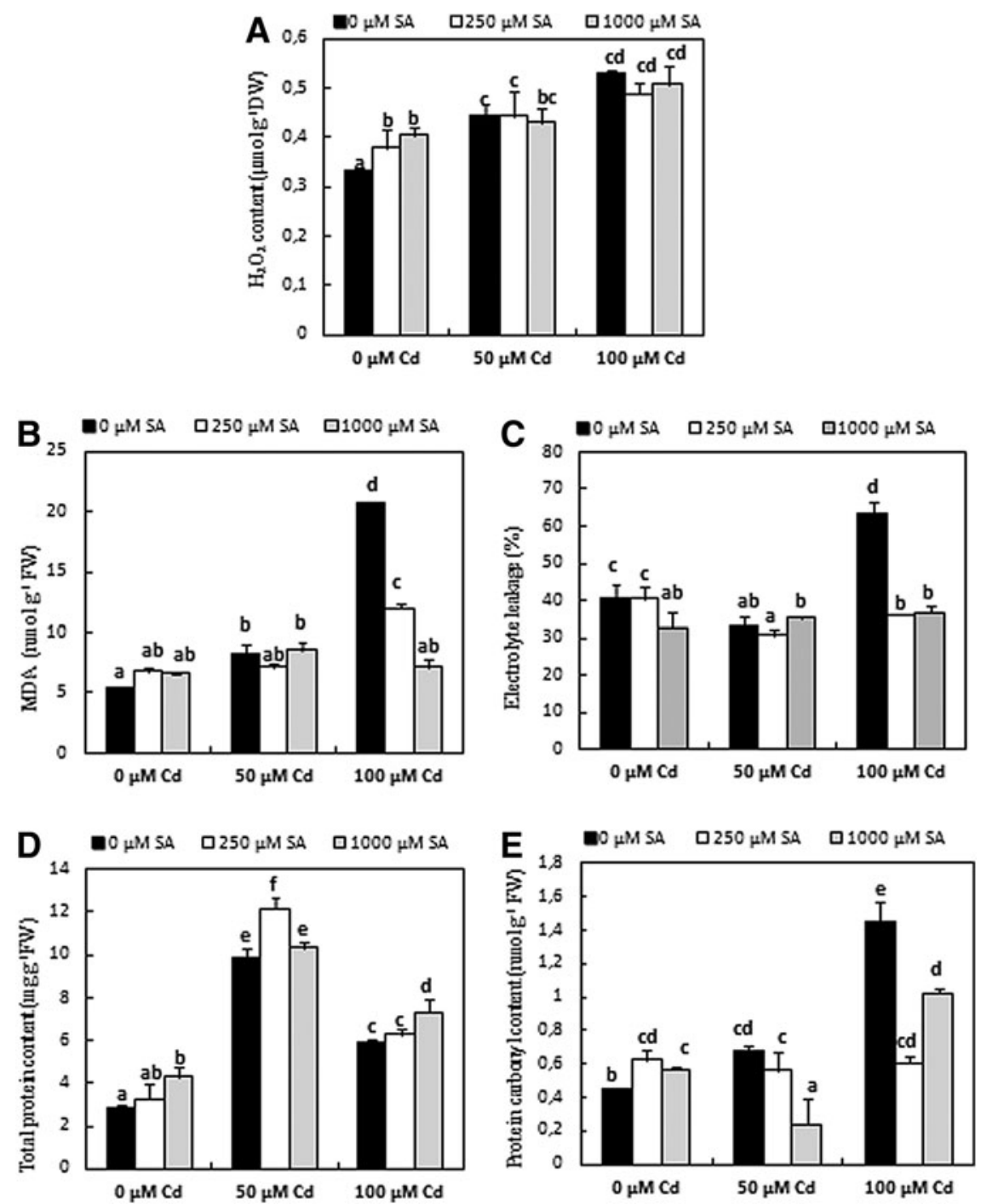

FIG. 2. The effects of salicylic acid (SA) on hydrogen peroxide content (A), lipid peroxidation (B), electrolyte leakage (C), total protein (D), and protein carbonyl (E) contents in roots of flax plantlets under cadmium (Cd) stress. Values are the means of 5 replicate experiments \pm SE. Bars with different letters are statistically different at $p \leq 0.05$.

8-h SA pretreatment alone $(1000 \mu \mathrm{M})$ decreased it, and the effect was similar with the addition of Cd (50 or $100 \mu \mathrm{M})$ (Fig. 3A). After 10 days of Cd stress, root GPX and APX showed significantly higher activities levels than control, especially at $100 \mu \mathrm{M}$ Cd. A significantly enhanced response in both enzymes activities occurred by 8-h SA pretreatment followed by Cd exposure (Fig. 3B and C). In contrast, SOD activity was suppressed by $\mathrm{Cd}$ addition in the medium. Cd treatment caused an increase of $28 \%$ and $50 \%$ upon exposure to 50 and $100 \mu \mathrm{M} \mathrm{Cd}$, respectively (Fig. 3D). However, SA (250 or $1000 \mu \mathrm{M}$ ) inhibited Cd-decreased activity of SOD (Fig. 3D).

At 50 and $100 \mu \mathrm{M} \mathrm{Cd}$, the total antioxidant capacities increased with respect to the control plantlets (Fig. 4A and B). These Cd-induced increases were further improved by the 8-h SA pretreatment but in a dose-dependent manner. In terms of $100 \mu \mathrm{M} \mathrm{Cd}$, the maximum values have been registered at $250 \mu \mathrm{M}$ SA for both analyzed tests (Fig. 4A and B).

The amount of total lipid (TL) evaluated from the amount of total fatty acids was changed in Cd-treated roots and highly dependent on the metal concentration in the medium (Fig. 5).
At 50 and $100 \mu \mathrm{M} \mathrm{Cd}$, TL content of roots was $40.5 \%$ and $79 \%$ reduced, respectively, compared to control. Only at the highest Cd dose did 8-h SA pretreatment significantly enhance TL content in roots of flax plantlets (Fig. 5). In controls, the fatty acids composition of TL in flax roots contained mostly linolenic (C18:3), linoleic (C18:2), and palmitic (C16:0) acids (about $87 \%$ of the total fatty acids). $\mathrm{CdCl}_{2}(50$ and $100 \mu \mathrm{M})$ showed a slight statistically significant increase in the degree of fatty acid unsaturation in the roots (Table 2). The impact of $\mathrm{Cd}$ on the fatty acid composition of root cell membranes became more evident at higher concentration. The SA-induced change in the lipid unsaturation was similar to that caused by $\mathrm{Cd}$. Interestingly, when Cd was added in the medium (50 or $100 \mu \mathrm{M}$ ), 8-h pretreatment with SA $(250 \mu \mathrm{M})$ significantly increased the total extent of fatty acid unsaturation (Table 2).

\section{Discussion}

In this work, we investigate the potential defense mechanisms enabling primed plantlets to overcome $\mathrm{Cd}$-induced 

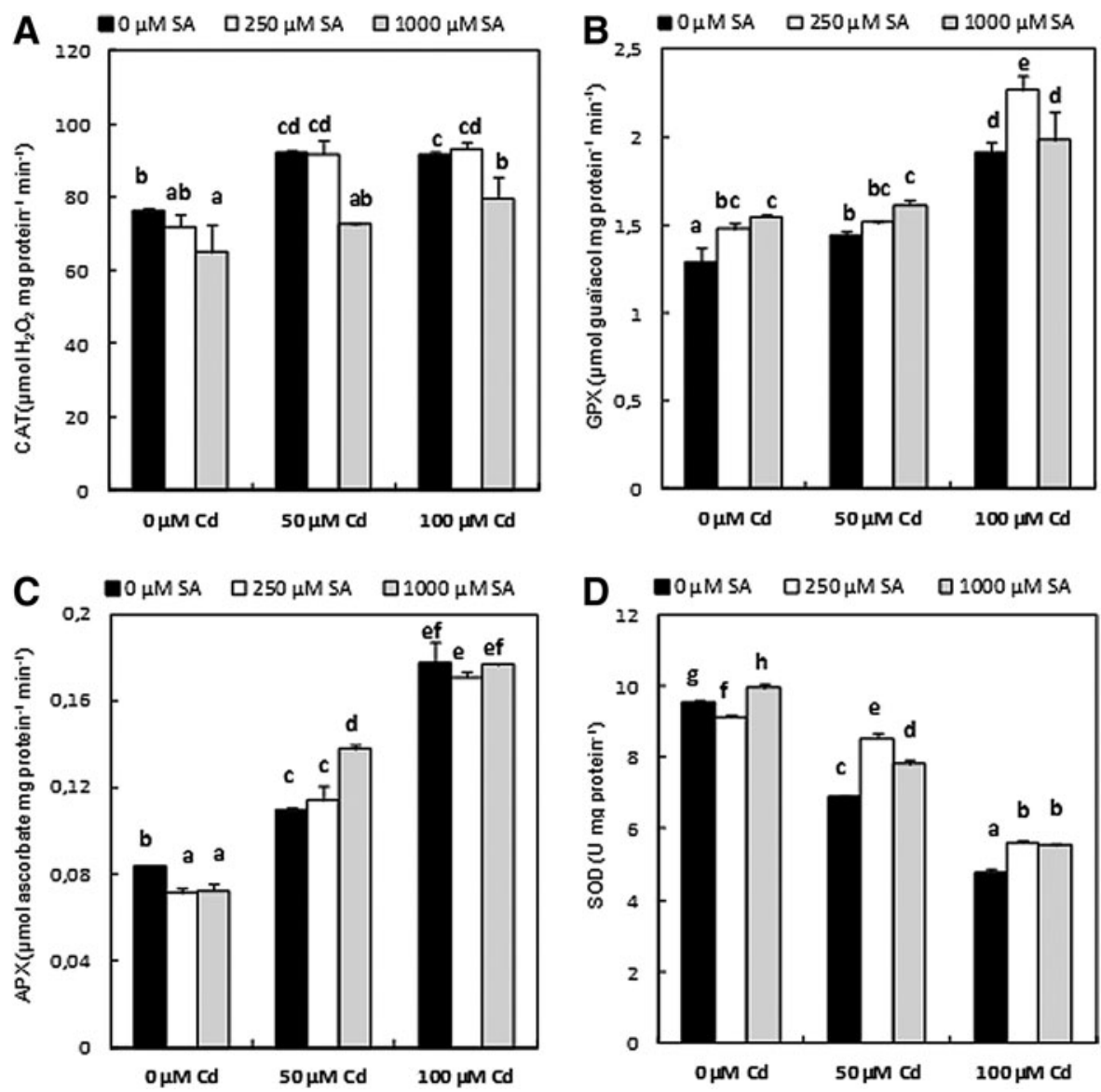

FIG. 3. The effects of salicylic acid (SA) on the activities of catalase (CAT) (A), guaïcol peroxidase (GPX) (B), ascorbate peroxidase (APX) (C), and superoxide dismutase (SOD) (D) in roots of flax plantlets under cadmium (Cd) stress. Values are the means of 5 replicate experiments \pm SE. Bars with different letters are statistically different at $p \leq 0.05$.

oxidative damage to proteins and membranes (oxidation, loss of membrane fluidity and integrity, and the degradation of its components). Flax roots exposed for 10 days to 50 and $100 \mu \mathrm{M}$ $\mathrm{CdCl}_{2}$ had reduced dry weight and the morphological characters such as surface, volume, and diameter (Table 1). These alterations observed at the root level could be a consequence of Cd interference in plant metabolism (Liu et al., 2007), as well as modification in antioxidative enzyme activities (Rodriguez-Serrano et al., 2009).

The results showed that $\mathrm{Cd}$ decreased the biomass and induced the generation of $\mathrm{H}_{2} \mathrm{O}_{2}$ (Fig. 2A), which agrees with previous reports by Schützendübel and Polle (2002) for Scots
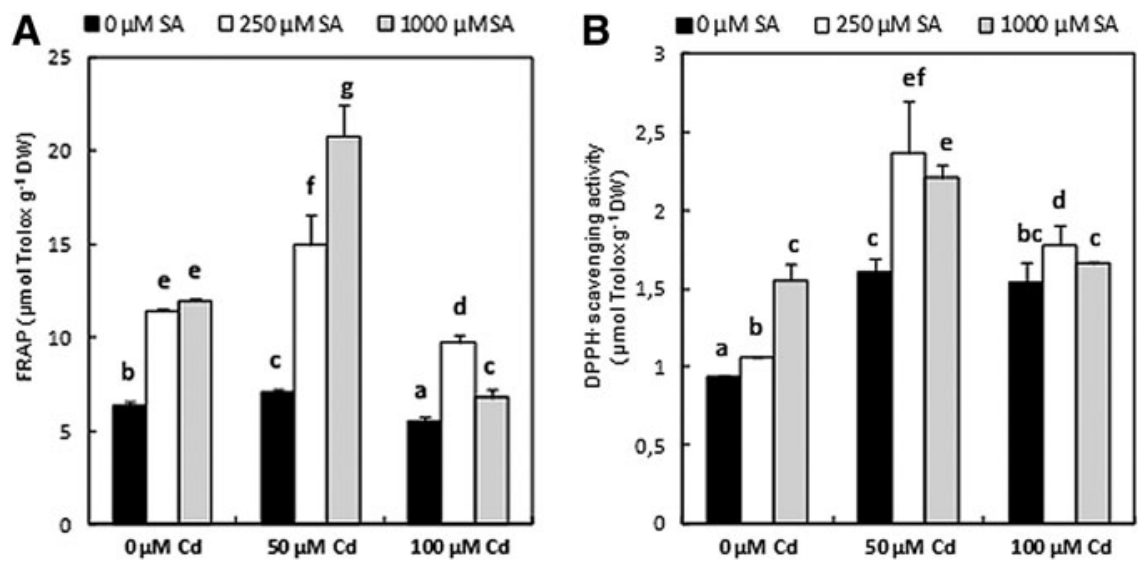

FIG. 4. The effects of salicylic acid (SA) on ferric reducing antioxidant power (FRAP) (A) and DPPH· scavenging activity (B) in roots of flax plantlets under cadmium $(\mathrm{Cd})$ stress. Values are the means of 5 replicate experiments \pm SE. Bars with different letters are statistically different at $p \leq 0.05$. 


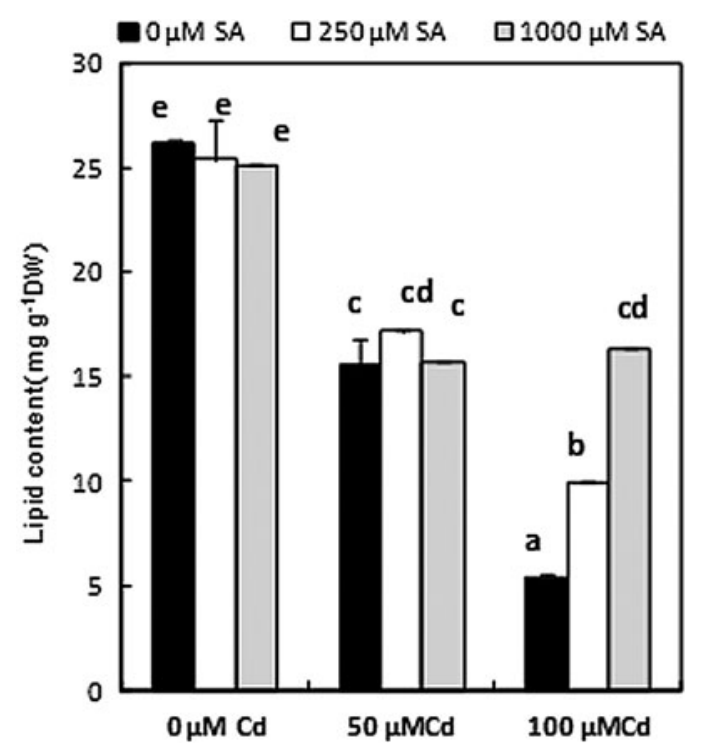

FIG. 5. The effects of salicylic acid (SA) on total lipid content in roots of flax plantlets under cadmium (Cd) stress. Values are the means of 5 replicate experiments \pm SE. Bars with different letters are statistically different at $p \leq 0.05$.

pine, Ortega-Villasante et al. (2007) for alfalfa, Liu et al. (2008) for tomato, and Gonçalves et al. (2009) for potato. Cd-increased $\mathrm{H}_{2} \mathrm{O}_{2}$ concentration led to lipid peroxidation, causing membrane damage and leakage of electrolytes (Schützendübel and Polle 2002). However, in this experiment, the reduction in biomass, induction of electrolyte leakage, lipid peroxidation, and protein carbonylation were partially alleviated by applying SA to Cd-treated flax plantlets (Table 1 and Fig. 2B-E). This is linked to the SA- increased levels of GPX, APX and SOD activities under Cd stress (Fig. 3B, C, and D).

Superoxide radicals generated by oxidative metabolism were dismutated into $\mathrm{H}_{2} \mathrm{O}_{2}$ and $\mathrm{O}_{2}$ by SOD which acts as a first line of defense response in planta (Gratão et al., 2012, Radwan, 2012). The increased SOD activity due to SA might protect biomolecules from being attacked by superoxide radicals. It has been shown that exogenous SA application resulted in the alleviation of Cd-induced ROS overproduction in Arabidopis thaliana (Zhang and Chen, 2011) and maize seedlings (Radwan, 2012). Consequently, the lower level of lipid peroxidation, and thus the lower degree of membrane damage, might result from the SA-increased activity of SOD enzyme in flax roots (Fig. 3D).

Protein carbonylation may occur due to direct oxidation of amino acid side chains (e.g., proline, arginine, lysine, and threonine) by ROS and/or by protein reactions with lipid peroxidation products, such as 4-hydroxy-2-nonenal (HNE). Numerous studies have shown that $\mathrm{Cd}$ bioaccumulation lead to the oxidation of proteins in plant tissues (Romero-Puertas et al., 2002, Djebali et al., 2008, Douchiche et al., 2010), which is in agreement with our present findings (Fig. 2E). On the other hand, SA-decrease of lipid peroxidation may partially contribute to the $\mathrm{Cd}$ alteration effect on protein content in roots (Fig. 2B). In fact, several studies reported the increase in total protein content and formation of new proteins in pea due to SA treatment (Katoch, 2007, Çag et al., 2009).

Plant membranes are the first functional structure to come into contact with toxic metals; it is considered to play a critical role in metal tolerance of plants. The presence of polyunsaturated fatty acids in the plasma membrane results in increased membrane permeability to ions (Hanzel and Williams, 1990). The depletion of unsaturated fatty acids may also indicate lipid peroxidation elicited by $\mathrm{Cd}$ (Ben youssef et al., 2005; Djebali et al., 2005). In a study of pea roots, Hernández and Cooke (1997) reported a similar decrease in the fatty acid saturation in response to Cd stress. SA acts in response to the Cd-induced changes in fatty acid saturation, [i.e., the increased unsaturation in the roots (Table 2)]. Moreover, it can be assumed that the defensive role of SA against Cd toxicity might be credited to its function in regulating root membrane permeability.

Other mechanisms involved in the prevention of Cd-induced membrane damage require the synthesis of antioxidant enzymes. In fact, an increase in antioxidant enzyme activities after Cd treatment has been detected in Hordeum vulgare (Guo et al., 2004); O. sativa (Hsu and Kao, 2004); Triticum aestivum (Khan et al., 2007); Brassica juncea (Mobin and Khan, 2007); Vigna mungo (Singh et al., 2008); C. arietinum (Hassan et al., 2008). In this study, Cd affected SOD, CAT, APX, and GPX

Table 2. Effect of SA on Fatty Acid of Total Lipids Composition in Root of 16-Day-Old Flax Plantlets Subjected During 10 Days to Cd Toxicity

\begin{tabular}{|c|c|c|c|c|c|c|c|c|}
\hline \multicolumn{2}{|c|}{ Fatty acids (\%TL) } & \multicolumn{7}{|c|}{ Roots } \\
\hline $\mathrm{SA}(\mu \mathrm{M})$ & $\mathrm{Cd}(\mu \mathrm{M})$ & C16:0 & C16:1 & C18:0 & C18:1 & C18:2 & C18:3 & Unsaturation \\
\hline 0 & 0 & $30.22 \pm 1.68^{\mathrm{ab}}$ & $\operatorname{Tr}$ & $5.96 \pm 0.60^{\mathrm{a}}$ & $6.62 \pm 0.82^{\mathrm{ab}}$ & $43.78 \pm 0.58^{\mathrm{bc}}$ & $13.40 \pm 0.33^{\mathrm{ab}}$ & $69.77 \pm 1.66^{\mathrm{a}}$ \\
\hline 0 & 50 & $29.75 \pm 0.15^{\mathrm{c}}$ & $\mathrm{Tr}$ & $6.88 \pm 0.34^{\mathrm{ab}}$ & $6.74 \pm 0.24^{\mathrm{ab}}$ & $42.08 \pm 0.18^{b}$ & $14.55 \pm 0.52^{\mathrm{b}}$ & $70.25 \pm 0.13^{\mathrm{a}}$ \\
\hline 0 & 100 & $27.13 \pm 0.83^{\mathrm{a}}$ & $\mathrm{Tr}$ & $8.19 \pm 0.29^{b c}$ & $8.15 \pm 0.32^{b c}$ & $42.51 \pm 0.54^{\mathrm{b}}$ & $13.94 \pm 0.62^{\mathrm{ab}}$ & $72.78 \pm 0.54^{\mathrm{b}}$ \\
\hline 250 & 0 & $30.02 \pm 0.73^{c}$ & $\mathrm{Tr}$ & $6.04 \pm 0.90^{\mathrm{a}}$ & $6.21 \pm 0.77^{\mathrm{a}}$ & $43.55 \pm 2.29^{b c}$ & $14.18 \pm 0.12^{\mathrm{b}}$ & $69.99 \pm 0.74^{\mathrm{a}}$ \\
\hline 250 & 50 & $27.45 \pm 1.00^{\mathrm{a}}$ & $\operatorname{Tr}$ & $7.63 \pm 0.13^{\mathrm{b}}$ & $7.73 \pm 0.04^{\mathrm{b}}$ & $41.97 \pm 1.30^{\mathrm{b}}$ & $15.21 \pm 2.48^{C}$ & $72.55 \pm 1.00^{\mathrm{b}}$ \\
\hline 250 & 100 & $28.43 \pm 0.73^{\mathrm{ab}}$ & $\mathrm{Tr}$ & $8.11 \pm 0.06^{b c}$ & $8.14 \pm 0.09^{b c}$ & $39.87 \pm 0.47^{\mathrm{a}}$ & $15.43 \pm 0.12^{C}$ & $71.55 \pm 0.73^{\mathrm{ab}}$ \\
\hline 1000 & 0 & $29.72 \pm 0.15^{c}$ & $\operatorname{Tr}$ & $6.02 \pm 0.67^{\mathrm{a}}$ & $5.85 \pm 0.45^{\mathrm{a}}$ & $44.66 \pm 3.20^{c}$ & $13.74 \pm 2.23^{\mathrm{ab}}$ & $70.28 \pm 0.15^{a}$ \\
\hline 1000 & 50 & $30.07 \pm 1.16^{c}$ & $\mathrm{Tr}$ & $7.22 \pm 0.12^{b}$ & $7.52 \pm 0.19^{b c}$ & $42.52 \pm 0.4^{\mathrm{b}}$ & $12.70 \pm 0.67^{a}$ & $69.94 \pm 1.15^{\mathrm{a}}$ \\
\hline 1000 & 100 & $28.41 \pm 0.45^{\mathrm{ab}}$ & $\mathrm{Tr}$ & $8.02 \pm 0.35^{\mathrm{bc}}$ & $8.09 \pm 0.28^{\mathrm{bc}}$ & $41.51 \pm 1.00^{\mathrm{b}}$ & $13.98 \pm 0.04^{\mathrm{ab}}$ & $71.59 \pm 0.41^{\mathrm{ab}}$ \\
\hline
\end{tabular}

${ }^{a}$ Data are means of three independent experiments $( \pm \mathrm{SE}) .{ }^{\mathrm{b}}$ Means with different letters indicate statistically different results at $p \leq 0.05$, according to Tukey's (HSD) test, (Tr, trace). 
activities in flax plantlets, with their impact being higher at $100 \mu \mathrm{M} \mathrm{Cd}$ (Fig. 3). In the roots, Cd, especially at this concentration, tended to increase their activities (with the exception of SOD). The severe Cd-decrease in SOD activity might be caused by the continuous competition between $\mathrm{Zn}$ and $\mathrm{Cd}$ for the same sites in $\mathrm{Cu} / \mathrm{Zn}$ SOD. Similarly, Rodriguez-Serrano et al. (2009) showed that Cd-decrease in Ca lead to $\mathrm{Cu} / \mathrm{Zn}$ SOD downregulation, which resulted in the overproduction of superoxide radicals in Pisum sativum.

However, our results showed that the 8-h SA pretreatment caused a significant increase in GPX, APX, and SOD, and a decrease in CAT activity in Cd-treated plantlets (Fig. 3A-D). In barley seedlings treated with Cd, Metwally et al. (2003) reported that total root $\mathrm{APX}$ activity reflected the cytosolic isoforms and the $\mathrm{Cd}$ response was fully suppressed by SA. Conversely, the same authors reported that CAT activity and expression level decreased upon SA pretreatment. According to Janda et al. (1999), a new peroxidase isoform was detected in maize treated with SA, even the total activity did not increase significantly.

The effect of SA on the activation of SOD may facilitate the integrity of membrane structures of root cells, because SOD is involved in the processes of lipid peroxidation deactivation (Zenkov et al., 2001). But, the significance of catalase inhibition could be partly due to the possible binding of SA to CAT. In fact, SA has proved capable of binding directly to CAT enzyme (Chen et al., 1993), isolated from tobacco, inhibiting its activity (Conrath et al., 1995). The in vitro SA catalase-inhibiting effect has also been demonstrated in many other plant species, such as Arabidopsis, tomato, cucumber (Sánchez-Casas and Klessig, 1994), and tobacco (Horváth et al., 1998).

Numerous studies showed that exogenous application of SA can influence the antioxidant capacity of plant cells (Janda et al., 2003, Ananieva et al., 2004, Radwan, 2012). Besides, since adaptation to oxidative stress involves not only the regulation of the synthesis and repair of proteins but also enhanced antioxidant capacity (Ananieva et al., 2004), two different tests were used in this work to confirm the SAinduced changes in antioxidant activities of Cd-treated plantlets (Fig. 4A and B). In roots, Cd stress significantly increased FRAP and DPPH-radical scavenging activity. This effect was improved by SA in Cd-stressed plantlets.

\section{Conclusion}

To summarize, it was demonstrated that the exogenous 8-h SA pretreatment may improve the tolerance of flax roots to Cd-induced oxidative stress. Moreover, SA-enhanced antioxidant enzymes SOD, APX, and GPX maintained ROS such as superoxide radicals at minimum levels with respect to $100 \mu \mathrm{M}$ Cd treatment. Therefore, SA-increase of the total antioxidant capacities in Cd-treated flax roots avoids its deleterious effects in cell membranes. For these reasons, we can conclude that due to $\mathrm{Cd}$ high toxicity and its potent freeradical scavenging ability, SA-induced priming could be used as a potential preventive action taken to limit oxidative damages.

\section{Acknowledgments}

This research was supported by a grant from the Tunisian Ministry of Higher Education, Scientific Research and Tech- nology. We gratefully acknowledge Dr. Michael Deyholos (University of Alberta, Canada) for his careful reading of the manuscript and Ms. Géraldine Dambry (Service Recherche/ Laboratoire Pathologie et Biologie du lin, France) for her gracious help to provide us the flax seeds.

\section{Author Disclosure Statement}

No competing financial interests exist.

\section{References}

Aeby H. (1984). Catalase in vitro. Meth Enzymol 105, 121-126. Ananieva EA, Christov KN, and Popova LP. (2004). Exogenous treatment with salicylic acid leads to increased antioxidant capacity in leaves of barley plants exposed to paraquat. J Plant Physiol 161, 319-328.

Apel K, and Hirt H (2004). Reactive oxygen species: Metabolism, oxidative stress, and signal transduction. Ann Rev Plant Biol 55, 373-399.

Balestrasse KB, Gardey L, Gallego SM, and Tomaro ML. (2001). Response of antioxidant defense system in soybean nodules and roots subjected to cadmium stress. Aust J Plant Physiol 28, 497-504.

Beauchamp C, and Fridovich I. (1971). Superoxide dismutase, improved assays and an assay applicable to acrylamide gels. Anal Biochem 44, 276-287.

Belkhadi A, Hediji H, Abbes Z, et al. (2010). Effects of exogenous salicylic acid pre-treatment on cadmium toxicity and leaf lipid content in Linum usitatissimum L. Ecotox Environ Safe 73, 1004-1011.

Ben Youssef N, Nouairi I, Ben Temime S, et al. (2005). Cadmium effects on lipid metabolism of rape (Brassica napus L.). C R Biol 328, 745-757.

Benzie IFF, and Strain JJ. (1996). The ferric reducing ability of plasma (FRAP) as a measure of "antioxidant power": The FRAP assay. Anal Biochem 239, 70-76.

Bradford MM. (1976). A rapid and sensitive method for the quantitation of microgram quantities of protein utilizing the principle of protein-dye binding. Anal Biochem 72, 248-254.

Brand-Williams W, Cuveleir ME, and Berset C. (1995). Use of a free radical method to evaluate antioxidant activity. Lebensmittel-Wissenschaft und -Technologie 28, 25-30.

Buege JA, and Aust SD. (1972). Microsomal lipid peroxidation. Methods Enzymol. 52, 302-310.

Çag S, Cevahiröz G, Sarsag M, and Gören-Saglam N. (2009). Effect of salicylic acid on pigment, protein content and peroxides activity in excised sunflower cotyledons, Pak J Bot 41, 2297-2303.

Chen Z, Silva H, and Klessing DF. (1993). Active oxygen species in the induction of plant systemic acquired resistance by salicylic acid. Science 262, 1883-1886.

Choi SM, Song HR, Han SK, et al. (2012). HDA19 is required for the repression of salicylic acid biosynthesis and salicylic acid-mediated defense responses in Arabidopsis. Plant J 71, 135-146.

Choudhury S, and Panda SK. (2004). Role of salicylic acid in regulating cadmium induced oxidative stress in Oryza sativa L. roots. Bulg J Plant Physiol 30, 95-110.

Conrath U, Chen Z, Ricigliano JR, and Klessig DF. (1995). Two inducers of plant defense responses, 2,6-dichloroisonicotinic acid and salicylic acid, inhibit catalase activity in tobacco. Proc Natl Acad Sci USA 92, 7143-7147.

Djebali W, Zarrouk M, Brouquisse R, El Kahoui S, Limam F, Ghorbel MH, and Chaibi W. (2005). Ultrastructure and lipid 
alterations induced by cadmium in tomato (Lycopersicon esculentum) chloroplast membranes. Plant Biol 7, 258-368.

Djebali W, Gallusci P, Polge C, et al. (2008). Modifications in endopeptidase and $20 S$ proteasome expression and activities in cadmium treated tomato (Solanum lycopersicum L.) plants. Planta 227, 625-639.

Douchiche O, Soret-Morvan O, Chaibi W, Morvan C, and Paynel F. (2010). Characteristics of cadmium tolerance in 'Hermes' flax seedlings: Contribution of cell walls. Chemosphere 81, 1430-1436.

Drazic G, and Mihailovic N. (2005). Modification of cadmium toxicity in soybean seedlings by salicylic acid. Plant Physiol 168, 511-517.

Durrant WE, and Dong X. (2004). Systemic acquired resistance. Annu Rev Phytopath 42, 185-209.

Ferreres F, Sousa C, Valentao P, Seabra RM, Pereira, JA, and Andrade PB. (2007). Tronchuda cabbage (Brassica oleracea L. var. costata DC) seeds: Phytochemical characterization and antioxidant potential. Food Chem 101, 549-558.

Fobert PR, and Despres C. (2005). Redox control of systemic acquired resistance. Curr Opin Plant Biol 8, 378-382.

Foyer CH, and Noctor G. (2005). Redox homeostasis and antioxidant signaling: A metabolic interface between stress perception and physiological responses. Plant Cell 17, 1866-1875.

Gallego SM, Pena LB, Barcia RA, et al. (2012). Unravelling cadmium toxicity and tolerance in plants: Insight into regulatory mechanisms. Environ Exp Bot 83, 33-46.

Garcés R, and Mancha M. (1993). One-step lipid extraction and fatty acid methyl esters preparation from fresh plant tissues. Anal Biochem 211, 139-143.

Gichner T, Patkova Z, Szakova J, and Demnerova K. (2004). Cadmium induces DNA damages in tobacco roots, but no DNA damage, somatic mutations orhomologous recombinations in tobacco leaves. Mutat Res Genet Toxicol Environ Mut 559, 49-57.

Gonçalves JF, Tabaldi LA, Cargnelutti D, et al. (2009). Cadmiuminduced oxidative stress in two potato cultivars. Biometals 22, 779-792.

Gratão PL, Polle A, Lea PJ, and Azevedo RA. (2005). Making the life of heavy metal-stressed plants a little easier. Funct Plant Biol 32, 481-494.

Gratão PL, Monteiro CC, Carvalho RF, et al. (2012). Biochemical dissection of diageotropica and Never ripe tomato mutants to Cd stressful conditions. Plant Physiol Biochem 56, 79-96.

Guo T, Zhang G, Zhou M, Wu F, and Chen J. (2004). Effect of aluminium and cadmium toxicity on growth and antioxidant enzyme activities of two barley genotypes with different $\mathrm{Al}$ resistance. Plant Soil 258, 241-248.

Guo B, Liang YC, Zhu YG, and Zhao FJ. (2007). Role of salicylic acid in alleviating oxidative damage in rice roots (Oryza sativa) subjected to cadmium stress. Environ Pollut 147, 743-749.

Hanzel JR, and Williams EE. (1990). The role of alteration in membrane lipid composition in enabling physiological adaptation of organisms to their physical environment. Prog Lipid Res 29, 167-227.

Hao L, Zhao Y, Jin DD, et al. (2012). Salicylic acid-altering Arabidopsis mutants response to salt stress. Plant Soil 354, 81-95.

Hassan MJ, Zhang G, and Zhu Z. (2008). Influence of cadmium toxicity on plant growth and nitrogen uptake in rice as affected by nitrogen form. J Plant Nutr 31, 251-262.

Hayat S, Hasan SA, Fariduddin Q, and Ahmad A. (2008). Growth of tomato (Lycopersicon esculentum) in response to salicylic acid under water stress. J Plant Int 3, 297-304.
Hédiji H, Djebali W, Cabasson C, et al. (2010). Effects of longterm cadmium exposure on growth and metabolomic profile of tomato plants. Ecotox Environ Safe 73, 1965-1974.

Hendry GAF, Baker AJM, and Ewart CF. (1992). Cadmium tolerance and toxicity, oxygen radical processes and molecular damages in $\mathrm{Cd}$ tolerant and $\mathrm{Cd}$ sensitive clones of Holcus lanatus. Acta Bot Neert 40, 271-281.

Hernández LE, and Cooke DT. (1997). Modifications of the root plasma membrane lipid composition of cadmium-treated $\mathrm{Pi}$ sum sativum. J Exp Bot 48, 1375-1381.

Horváth DM, Huang DJ, and Chua NH. (1998). Four classes of salicylate-induced tobacco genes. Mol Plant Micro Inter 11, 895-905.

Hsu YT, and Kao CH. (2004). Cadmium toxicity is reduced by nitric oxide in rice leaves. Plant Growth Regul 42, 227-238.

Janda T, Szalai G, Tari I, and Páldi E. (1999). Hydroponic treatment with salicylic acid decreases the effect of chilling injury in maize (Zea mays L.) plants. Planta 208, 175-180.

Janda T, Szalai G, Rios-Gonzalez K, Veisz O, and Páldi E. (2003). Comparative study of frost tolerance and antioxidant activity in cereals. Plant Sci 164, 301-306.

Katoch R. (2007). Induction of apathogenesis-related protein in pea after treatment with inducers or inoculation with Erysiphe polygoni. J Veg Sci 12, 15-25.

Khan NA, Samiullah SS, and Nazar R. (2007). Activities of antioxidative enzymes, sulphur assimilation, photosynthetic activity and growth of wheat (Triticum aestivum) cultivars differing in yield potential under cadmium stress. J Agron Crop Sci 193, 435-444.

Krantev A, Yordanova R, Janda T, Szalai G, and Popova L. (2008). Treatment with salicylic acid decreases the effect of cadmium on photosynthesis in maize plants. J Plant Physiol 165, 920-931.

Landberg T, and Greger M. (2002). Differences in oxidative stress in heavy metal resistant and sensitive clones of Salix viminalis. J Plant Physiol 159, 69-75.

Liu XL, Zhang SZ, Shan XQ, and Christie P. (2007). Combined toxicity of cadmium and arsenate to wheat seedlings and plant uptake and antioxidative enzyme responses to cadmium and arsenate co-contamination. Ecotox Environ Safe 68, 305-313.

Liu KL, Shen L, Wang JQ, and Sheng JP. (2008). Rapid inactivation of chloroplastic ascorbate peroxidase is responsible for oxidative modification to rubisco in tomato (Lycopersicon esculentum) under cadmium stress. J Integrat Plant Biol 50, 415-426.

Metwally A, Finkemeier I, Georgi M, and Dietz KJ. (2003). Salicylic acid alleviates the cadmium toxicity in barley seedlings. Plant Physiol 132, 272-281.

Mishra S, Srivastava S, Tripathi RD, Kumar R, Seth CS, and Gupta DK. (2006). Lead detoxification by coontail (Ceratophyllum demersum L.) involves induction of phytochelatins and antioxidant system in response to its accumulation. Chemosphere 65, 1027-1039.

Mobin M, and Khan NA. (2007). Photosynthetic activity, pigment composition and antioxidative response of two mustard (Brassica juncea) cultivars differing in photosynthetic capacity subjected to cadmium stress. J Plant Physiol 164, 601-610.

Nakano Y, and Asada K. (1981). Hydrogen peroxide is scavenged by ascorbate-specific peroxidase in spinach chloroplast. Plant Cell Physiol 22, 676-690.

O'Kane D, Gill V, Boyd P, and Burdon R. (1996). Chilling, oxidative stress and antioxidant responses in Arabidopsis thaliana callus. Planta 198, 371-377. 
Ortega-Villasante C, Hernandez LE, Rellan-Alvarez R, Del Campo FF, and Carpena-Ruiz RO. (2007). Rapid alteration of cellular redox homeostasis upon exposure to cadmium and mercury in alfalfa seedlings. New Phytol 176, 96-107.

Panda SK, and Patra HK. (2007). Effect of salicylic acid potentiates cadmium-induced oxidative damage in Oryza sativa L. Leaves. Acta Physiol Plant 29, 567-575.

Popova LP, Maslenkova LT, Yordanova RY, Ivanova AP, Krantev AP, Szalai G, and Janda T. (2009). Exogenous treatment with salicylic acid attenuates cadmium toxicity in pea seedlings. Plant Physiol Biochem 47, 224-231.

Radwan DEM. (2012). Salicylic acid induced alleviation of oxidative stress caused by clethodim in maize (Zea mays L.) leaves. Pest Biochem Physiol 102, 182-188.

Reznick AZ, and Packer L. (1994). Oxidative damage to protein: Spectrophotometric method for carbonyl assay. Methods Enzymol 233, 357-363.

Rodriguez-Serrano M, Romero-Puertas MC, Pazmino DM, et al. (2009). Cellular response of pea plants to cadmium toxicity: Cross talk between reactive oxygen species, nitric oxide, and calcium. Plant Physiol 150, 229-243.

Romero-Puertas MC, Palma JM, Gomez M, Del Río LA, and Sandalio LM. (2002). Cadmium causes the oxidative modification of proteins in pea plants. Plant Cell Environ 25, 677-686.

Sánchez-Casas P, and Klessig DF. (1994). A salicylic acid-binding activity and a salicylic acid-inhibitable catalase activity are present in a variety of plant species. Plant Physiol 106, 1675-1679.

Saruhan N, Saglam A, and Kadioglu A. (2012). Salicylic acid pretreatment induces drought tolerance and delays leaf rolling by inducing antioxidant systems in maize genotypes. Acta Physiol Plant 34, 97-106.

Schützendübel A, and Polle A. (2002). Plant responses to abiotic stresses: Heavy metal induced oxidative stress and protection by mycorrhization. J Exp Bot 53, 1351-1365.

Shi GR, Cai QS, Liu QQ, and Wu L. (2009). Salicylic acidmediated alleviation of cadmium toxicity in hemp plants in relation to cadmium uptake, photosynthesis and antioxidant enzymes. Acta Physiol Plant 31, 969-977.

Singh S, Khan NA, Nazar R, and Anjum NA. (2008). Photosynthetic traits and activities of antioxidant enzymes in blackgram (Vigna mungo L. Hepper) under cadmium stress. Am J Plant Physiol 3, 25-32.

Smeets K, Ruytnx J, Semane B, et al. (2008). Cadmium induced transcriptional and enzymatic alterations related to oxidative stress. Environ Exp Bot 63, 1-8.

Tamás L, Durcekova K, Haluskova L, Huttova J, Mistrik I, and Olle M. (2007). Rhizosphere localized cationic peroxidase from barley roots is strongly activated by cadmium and correlated with root growth inhibition. Chemosphere 66, 1292-1300.

Zawoznik M, Groppa MD, Tomaro ML, and Benavides MP. (2007). Endogenous salicylic acid potentiates cadmiuminduced oxidative stress in Arabidopsis thaliana. Plant Sci 173, 190-197.
Zenkov NK, Lankin VE, and Menshchikova EV. (2001). Okislitel'nyi stress (Oxidative Stress). Moscow, Nauka, pp. 280.

Zhang F, Zhang H, Xia Y, Wang G, Xu L, and Shen Z. (2011). Exogenous application of salicylic acid alleviates cadmium toxicity and reduces hydrogen peroxide accumulation in root apoplasts of Phaseolus aureus and Vicia sativa. Plant Cell Rep 30, 1475-1483.

Zhang WN, and Chen WL. (2011). Role of salicylic acid in alleviating photochemical damage and autophagic cell death induction of cadmium stress in Arabidopsis thaliana. Photochem Photobiol Sci 10, 947-955.

Address correspondence to: Aïcha Belkadhi

Département de Biologie

Unité de Recherche de Physiologie et Biochimie de la tolérance des plantes aux contraintes abiotiques

Faculté des Sciences de Tunis

Campus Universitaire

1060 Tunis

Tunisia

or

Department of Agronomy and Plant Breeding Institute of Sustainable Agriculture Spanish Council for Scientific Research (CSIC) Alameda del Obispo s/n 14080 Córdoba Spain

E-mail: aicha585@yahoo.ca

\section{Abbreviations Used}

APX $=$ ascorbate peroxidase

$\mathrm{CAT}=$ catalase

$\mathrm{Cd}=$ cadmium

$\mathrm{DPPH}=2,2^{\prime}$-diphenyl-1-picrylhydrazyl

$\mathrm{DW}=$ dry weight

FRAP $=$ ferric reducing antioxidant power

$\mathrm{GPX}=$ guaïcol peroxidase

$\mathrm{H}_{2} \mathrm{O}_{2}=$ hydrogen peroxide

$\mathrm{MDA}=$ malondialdehyde

$\mathrm{SA}=$ salicylic acid

$\mathrm{SOD}=$ superoxide dismutase (SOD)

$\mathrm{TL}=$ total lipid 